\title{
A Semantic Analysis on Bali United Chants
}

\author{
Anak Agung Putu Arsana \\ \{agungarsana@unmas.ac.id\}
}

Faculty of Teacher Training and Education, Universitas Mahasaraswati Denpasar

\begin{abstract}
Semantics is the study of meaning. The semantics study explains how meaning works in language. Semantics is one of linguistics elements, and deals with meaning and interpretation of the words, sentence structure, and symbols. It also deals with readers when improve their reading comprehension, in how they understand interpretation and others. In semantic, we study the meaning systematically and how language organize and express meaning [6]. Chant is a type of song with repetition, monotone of structure. It is also something sports fans love to do. Bali United is a football club in Bali Island. The club fans sing the chant before, during and after the football match. By listening the chants, we can get knowledge on how we appreciate the literature and background of the chants. The researcher is interested to do the research entitled "A semantic analysis on Bali United Chants". As a part of linguistics, semantic has lexical meaning and contextual meaning. The problems of this study are : (1) what are the lexical meaning in the Bali United chants? (2) What are contextual meaning in the Bali United chant. The researcher takes five popular chants of Bali United fans. This study used descriptive a method of descriptive qualitative which means the researcher analyzed and interpreted the research object of Bali United chants.[2] [11] There some steps in obtaining the data, first collecting the data sources from Bali United chants. Then, the researcher selects the chants which contain semantic elements, after that read and listened to the lyrics to get an understanding the content and meaning of the chants. Next, the researcher conducted and analyze the data collection and make conclusion. The findings of this study are : (1) lexical meaning on the Bali United chants (2) contextual meaning on the Bali United chants. The researcher expected that this study will give some benefits for the other researcher who are interested to study more about semantic.
\end{abstract}

Keywords: semantic, lexical meaning, contextual meaning, Bali United, chants

\section{Introduction}

Language is the system of speech sound, word and sentence used by humans to convey their mind and feeling [4]. Language allows people to communicate with great precision. Among people, language can be a communication device. Through communication, even spoken or written language, that the people can their minds, ideas, or opinion point of views, to another person. The aims of using language is to make sense of complex and abstract of our mind. Many kinds of languages are used by people in different places in different communities [9] [17]. Communication means life source of organizations because in organizations people can be involved. People cannot interact with each other without using language as a communication device. Communication can be defined as an exchange of facts, ideas, emotions, and opinions by two or more persons. Communication is derived from interaction between people who have something to share [12]. 
Where language is recognized as communication device, communication is an experience. Communication is described as, "an act of interchanging ideas, information, or messages from one person or place to another, via words or signs which are understood to both parties. It is a vital activity for any group of people, because it will elaborate the members of the group to cooperate together. Meanwhile, language is defined a sound system. Sound is defined as an impression of the nerve centre of eardrum vibration as a result of reacting due to changes in air pressure. [10]. It means that sounds in the process of language includes symbol of language itself which produced by human organs vocal.

Music means a rhythm, which reflects our physiological life. As well as, music consists of melody, sequence of sounds, that is collaborated with peoples' emotional life. Meanwhile, a chant is a type of song with a repetitive, monotonous structure. It's also something sports fans love to do. This chant is always chanted with music instrument in most football fans in Indonesia during the football match.

Indonesian football cannot be separated with the supporter or fans attendance in the stadium. In Bali, there is a football club named Bali United since 2015. Because of fanaticism and love, many fans of this club who come from around Bali attend Captain I Wayan Dipta Stadium in Gianyar Regency to support their loved club. They support it in each match when Bali United faces their opponent. The support reflected through chants during the match which is chanted together with music instrument such as bass drum and snare. Bali United fans is one of the creative football fans in Indonesia. They always combine the chant and music instruments with special choreography in each match.

Semantics is defined as a part of linguistics focused on the study the meaning in sentences and words. Semantics is a sub discipline of linguistics which is concerned on the study of meaning [5] Semantic also means study of meaning systematically, then semantic linguistically is the study of how language can be organized and expressed the meanings. [3] [7] [13] Semantics are meaning in which it strengthened the opinion the context built the meaning of a structure sentence [16]

Lexical meaning is a very small meaning unit in the language meaning system which can be distinguished from other similar unit. [1] [14] [15] Lexical meaning is stated as the word meaning when the word is categorized in isolation, whether in shape or form lexeme affixes whose meaning fixed more or less, as can be look up into a particular language dictionary. Contextual meaning is a lexeme or word meaning inside a context. A contextual defines as the term is used by embedding it in a larger expression containing its explanation [8]. The present study discusses about the analysis of semantic on the lexical and contextual meaning. In this research, the researcher chooses some Bali United chants to be analyzed semantically. The aims of this research are: (1) to find lexical meaning on the Bali United chants (2) to find contextual meaning on the Bali United chants.

\section{Research Methods}

This research uses method name descriptive qualitative because the researcher analysed and interpreted the Bali United chants as the research object. There some steps in obtaining the data, first collecting the data sources from Bali United chants. Then, the researcher selects the chants which contain semantic elements, after that read and listened to the lyrics to get an understanding the content and meaning of the chants. Next, the researcher conducted and analyse the data collection and make conclusion. 


\section{Results and Discussion}

After the researcher collected, he data, then the researcher analysed the chants semantically through lexical meaning and contextual meaning. There are five chants to be analysed in this research, they are : (1) Bali Belongs To Me, (2) We Love You Bali, (3) YNWA Bali United, (4) Bangga Mengawalmu, and (5) Semangat Puputan.

\section{Bali Belongs To Me}

This chant has lyrics as follows: "Bali Belongs To Me. An Island Pride the Dirty Water On The Rivers. No One Can Take Away Our Memory. Ooo..Ooo... Bali Belongs To Me!" In terms of lexical meaning, the researcher analyzed with the chant started with the word Bali Bali is the name of an island in Indonesia archipelago. Geographically, Bali is located between Java island and Lombok island. Bali is also well-known as the island of the Gods with beautiful dances and various ceremonies. It is one of the most popular tourism destinations in the world.

Now, Bali island has a football club named Bali United. In line 1, "Bali belongs to me", after the word "Bali", it is followed with "belongs" as a verb in simple present tense form because the word Bali itself before is a third singular subject. There is preposition "to" after the word "belongs', it has meaning as the preposition of possession and it must be followed by "me" as an object pronoun. In line 2, "An Island Pride The Dirty Water on The Rivers". A phrase an island consists of two words, they are an as an article followed by island which means a piece of land that is completely surrounded by water. Pride means a feeling of being pleased or satisfied because of something.

A phrase the dirty water consists of an article the where it is used to determine specific identity known, the word dirty is a group of adjective word which defined covered with an unclean substance. The word water is defined as a collaboration between oxygen and hydrogen (chemical formula: $\mathrm{H}_{2} \mathrm{O}$ ) with highly distinctive physical and chemical substances. The phrase On The Rivers consists of preposition of place on where it is used when referring to something with a surface, then an article the where it is used to determine specific identity known, it is the river.

Then, the researcher will analyse line 3, it is No One Can Take Away Our Memory. No One is an Indefinite Pronoun which is formed with a quantifier. The word can means an ability or capability, take away is a phrasal verb which means remove it from the previous place, so that they no longer possess it. The phrase our memory consists of possessive adjective our and the word memory which means the capability of the mind to store and remember information. The yell Ooooo..Oooo... is a kind of expression about pleasure when the fans express their pride.

In terms of contextual meaning, the researcher analyzed this chant in each lyric. In the first lyric, "Bali Belongs To Me" means Bali island where Bali United is existing is belonging to the fans, there is a feeling named pride of Bali in this lyric. Then, An Island Pride The Dirty Water On The Rivers tells us a fact that recently many rivers in Bali show the dirty water because of individual or group of people do not care to the environment so that it makes the river becomes dirty. But, this lyric tries to persuade the people or community to take care and keep the environment clean and healthy. No One Can Take Away Our Memory means the pride that has been built by the fans can not be taken away from their memory, it will stay in the memory forever. At last, Ooo..Ooo... Bali Belongs To Me!, it emphasize that Bali is belonging to the fans. 


\section{We Love You Bali}

This chant has lyrics as follows: "We Love You Bali, We Do. We Love You Bali, We Do. We Love You Bali, We Do. Heeeee....Bali We Love You". At first, the researcher analysed in lexical meaning point of view. The lyric We Love You Bali, We Do consists of subject pronoun we as the first plural person, the word love an expression of feeling that shows a person or people has an attention and care to something, or a great interest and pleasure in something, it is Bali. The word Do in We Do is a verb that refers to the previous statement, it is love. The fans wants to tell us that they truly love Bali.

In terms of contextual meaning, the researcher analysed the words We Love You Bali, We Do. This means the fans told their truly love to Bali. The fans have a very strong feeling of affection towards Bali itself which is represented into Bali United. They absolutely love Bali and Bali United, this statement are said repeatedly in this chant.

\section{YNWA Bali United}

This chant has lyrics as follows : "Walk On....Walk On...With Hope, In Your Heart. And You'll Never Walk Alone..You'll Never Walk Alone.". The phrase walk on is mentioned in twice. It consists of a verb walk and preposition on, walk means move forward or backward at a regular pace by lifting and setting down foot on by one. Then, with hope consists of with which means a preposition, it requires a noun as its object. Hope can be analysed as to look forward to with desire and reasonable confidence or to believe, desire, or trust. In Your Heart consists of preposition of place in which means a location or place, possessive adjective your which means a possession and heart which means a kind of human vital organ that pumps the blood in the body through the system of circulatory, then supply oxygen and some nutrients to the tissues followed by removing carbon dioxide and other wastes.

The words You'll never walk alone is very popular in the world. It is used as a slogan for some clubs in the world includes Bali United. You'll come from subject pronoun you and will. The word will itself is a modal auxiliary grammatically, it is used for saying what you expect to happen in the future. The word never means not ever or at no time. A verb walk means move forward by putting one foot in front of the other in a regular way. The word alone means having no one else present.

In terms of contextual meaning, 'Walk On....Walk On...With Hope, In Your Heart, And You'll Never Walk Alone" is a very meaningful lyric. It is a kind of promise of fans to the club that they will support the struggle of the club whenever and wherever. When the club is in victory or in the situation they strive, the fans will always stand by the club. The bond between club and the fans is unbreakable. Because of a club is not just a club, but it is a family which support one to another.

\section{Bangga Mengawalmu Pahlawan}

This chant has lyrics as follows : "Bangga Mengawalmu Hey Pahlawan. Bangga Bisa Bersamamu Kawan. Berjuang Meraih Kemenangan. Demi Sebuah Kehormatan. Ayo Majulah Bali United. Ayo Berjuang Bali United. Bermainlah Dengan Rasa Bangga Demi Lambang Bali Di Dada. Oooooo.....Ooooooo...Ooooooo...Ooooooo". The word Bangga or Proud means a feeling of being pleased or satisfied because of something. The word Mengawalmu or to guard you means watch over in order to protect you (Bali United), Hey Pahlawan or Hey Heroes means the players of Bali United who always keep fighting in each match of football competition. Bisa Bersamamu or Can Be With You means agree with or accompany with, Kawan or Friend means a person whom one knows and with whom one has a bond of mutual affection. 
The word Berjuang or Struggle means an act of strongly motivated striving. The word Meraih or Achieve means successfully bring about or reach. The word Kemenangan or victory is defined as an action when defeats an opponent in a battle or game, or other competition. The words Demi Sebuah Kehormatan or For The Honor means high respect or great esteems. In the second stanza, it is preceded by Ayo Majulah Bali United or Let Keep Moving Forward Bali United. Ayo Majulah means to accompany to advance in position or progress. The words Ayo Berjuang or Let Keep in Struggle means to accompany to act strongly. The Words Bermainlah dengan Rasa Bangga consists of Bermainlah or play, it means play football in the match and Rasa Bangga which means feeling of being pleased. The words Demi Lambang Bali di Dada or For The Badge of Bali in The Chest, in which Badge refers to a distinctive emblem worn as a mark of Bali, and In The Chest means a part of human body where this badge is put.

In terms of contextual meaning, Bangga Mengawalmu Hey Pahlawan, Bangga Bisa Bersamamu Kawan means there is a feeling named the pride to guard and to accompany the team named Bali United. Then, Berjuang Meraih Kemenangan Demi Sebuah Kehormatan means the fans always support the team to reach the victory for the honor. In the second stanza, Ayo majulah Bali United, Ayo Berjuang Bali United means the fan suggest and support to keep moving forward, to keep in struggle in every match and in every competition. Then, Bermainlah dengan Rasa Bangga, Demi Lambang Bali Di Dada means the fans wish the players should play in pride, in pleasure, seriously with love for the badge of Bali which is symbolized as Bali United badge in the jersey they are wearing.

\section{Semangat Puputan}

This chant has lyrics as follows : "Merah Membara Penuh Keberanian. Putih Suci Penuh Kejujuran. Hitam Kekal Kuat Tanpa Keraguan. Serdadu Tridatu Semangat Puputan. Walau Habis Suara Ini. Takkan Mati Semangat Ini. Teruslah Berjuang Walau Waktu Berlalu. Kami kan Selalu Disini. Untukmu Kebanggaan Kami. Untukmu Kebanggaan Kami. Untukmu Kebanggan Kami. Untukmu Bali Ku Tercinta...”. The title itself Semangat which means keep spirit and Puputan derived from the word Puput. Puput in Balinese means to run out, break up,die, done and finished. The word puput has the suffix 'an' becomes puputan. The puputan means all-out struggle in a war or can be concluded the war to the death in defeating the enemy, based on the history, this struggle sacrifices everything including the most meaningful property of body and soul, in the name of truth and independence.

The first stanza tells "Merah Membara Penuh Keberanian. Putih Suci Penuh Kejujuran. Hitam Kekal Kuat Tanpa Keraguan. Serdadu Tridatu Semangat Puputan”. There are three colours told here, they are merah (red), putih (white), and hitam (black), they are called Tridatu. The word Merah is followed by Membara, it is Burning Red or symbol of high fighting spirit, then Penuh Keberanian means the braveheart in fighting. Then, the word Putih followed by Suci is defined the colour of white is a symbol of holy. The holy of white means something is without any stain, and it means full of honesty. Then, the words Hitam Kekal means the black colour has a strong quality that means eternal or everlasting. These words followed by Kuat Tanpa Keraguan which means strong and no doubt.

After that, Serdadu Tridatu is a nickname of Bali United. Bali United has a Warrior or Serdadu, warrior can be defined as is the one who sacrifices himself for the good of others. Tridatu is the symbol of strength of the God of Balinese Hindu People which is represented in three colors they are red, white and black. Etymologically, the word Tridatu comes from two words, "Tri" meaning Three and "Daatu" meaning King. Therefore Tridatu is a symbol for the three main Gods in Hinduism: "Brahma (Red-Fire) The Creator", "Vishnu (Black-Water) The Keeper" and Shiva (White-Wind) The Dissolver". Tridatu is also symbolics of three elements. 
The creativity and bravery are symbolized in red element. Then, power and protection from bad spirits are symbolized in black element and last spirituality and goodness are symbolized in white element.

The second stanza tells "Walau Habis Suara Ini. Takkan Mati Semangat Ini. Teruslah Berjuang Walau Waktu Berlalu. Kami kan Selalu Disini. Untukmu Kebanggaan Kami. Untukmu Kebanggaan Kami. Untukmu Kebanggan Kami. Untukmu Bali Ku Tercinta...”. The first line Walau Habis Suara Ini. Takkan Mati Semangat Ini or "Although the fans have no more sound, the spirit is never end". The word Habis means no more or it can be said feels exhausted, Suara or Sound is a kind of vibrations that go through the air or another medium, can be listened when they reach a person's ears.

The words Takkan Mati means it has not finished yet, or still alive, and Semangat or spirit means the nonphysical part of a person which is the seat of emotions and character. Then, Teruslah Berjuang means keep fighting in the battle or in each match. The words Walau Waktu Berlalu or although "the time goes by" has the main core about the time. Time refers to progress of existence of the events in the past, present, and future. Berlalu or goes by refers to to move past, in space and time.

Then, "Kami kan Selalu Disini" or We will always be here, consists of subject pronoun we, modal auxiliary will, adverb of frequency always and adverb of place here. The words Untukmu Kebanggan Kami or For You Our Pride, contains Untukmu which refers to just for you, our club and Kebanggan Kami or Our Pride refers to Bali United is the fans' pride. Then, Untukmu Bali Ku Tercinta shows that Bali is my love, just for you Bali.

In terms of contextual meaning, this first stanza of this chant reflects the meaning of Tridatu into the struggle of Bali United players in each match. Balinese life and philosophy is wonderful and amazing, one of them is Tridatu The colors symbolize Fire, Water and Wind those with true faith in the power of Tridatu will find help in fighting wounds and ilnesses while appreciating the value of life itself. Therefore, Bali United has its own nickname Tridatu Warrior or Serdadu Tridatu. In the second stanza, it means the fans will not ever stop supporting till the end. Though the they have no sound anymore, they will always support and guard the team because Bali United is their pride.

\section{Conclusion}

Bali United Chant is a kind of song with repetition, the structure is monotone, chanted by football fans of Bali when they support the team named Bali United in each football match. The chants have lexical and contextual meaning semantically. The five main chants generally have the meaning to support the struggle of the team and raise the pride of Bali through Bali United Football Club. In lexical meaning, the words of Bali United chants contain the spirit and the value of the struggle of Bali which is represented into Bali United Football Club. In contextual meaning, the chant means songs that contain the support of Balinese people to the club and the pride of being Bali through the badge of Bali United.

\section{References}

[1] Asher, Nicholas. (2007). A Web of Words: Lexical Meaning in Context. Universite Paul Sabatier; France.

[2] Creswell, J. W. (1994). Research Design Qualitative and Quantitative Approaches. Saga Publications. London.

[3] Djajasudarma, Fatimah. T. (1993). Semantik 1: Pengantar ke Arah Ilmu Makna. Bandung: PT. Eresco 
[4] Hornby, A.S. 1995. Oxford Advanced Learner's Dictionary. Oxford University Press

[5] Kmpson, M Ruth. 1977. Semantic Theory. Cambridge University Press. London

[6] Kreidler, Charles W. 1998. Introducing English Semantics. Routledge 11 New Fetter Lane, London EC4P 4EE

[7] Leech, G.N. 1985. Semantics: The Study of Meaning Second Edition-Revised and Updated. England: Penguin Books

[8] Luo, Zhaohui. 2011. Contextual Analysis of Word Meanings in Type-Theoretical Semantic: Research grant UK

[9] Lyons, John. 1991. Introduction to Theoretical Linguistics.Cambridge: Cambridge University Press

[10] Muhammad.2011. Metode Penelitian Bahasa. Ar-Ruzz Media. Yogyakarta

[11] Moleong, Lexy. J. (2007). Metodologi Penelitian Kualitatif. Bandung: Remaja Rosdakarya

[12] Rivers, W.M: 1987. Interactive Language Teaching. Cambridge: Cambridge University Press

[13] Palmer. F.R. 1982. Semantics. Cambridge: Cambridge University Press

[14] Pateda, Mansoer. 2001. Semantik Leksikal. Jakarta : PT Rineka Cipta

[15] Smoliana, A. 2013. Semantic Comprehension of Lexical Content of the English Book Jackets. European Scientific Journal. Vol. 9 No. 29, pp: 43-54

[16] Tarigan, Henry Guntur. 2009. Pengajaran Semantik . Indonesia :Angkasa Bandung

[17] Wardhaugh, Ronald. 2006. An Introduction to Linguistics. Blackwell Publishing: Victoria, Australia 